\title{
APLIKASI REPRESENTASI REAL TIME GELOMBANG ELECTROCARDIOGRAPH DISKRIT
}

\author{
Azwar Riza Habibi ${ }^{1}$, Suci Imani Putri ${ }^{2}$, Lukman Hakim ${ }^{3}$ \\ STMIK ASIA Malang \\ e-mail: ${ }^{1}$ riza.bj@gmail.com, ${ }^{2}$ suci.imaniputri@asia.ac.id, ${ }^{3}$ bledeklukman@gmail.com
}

\begin{abstract}
ABSTRAK. Penelitian ini membuat metode untuk merepresentasikan secara real time durasi gelombang tiap siklus dari rekaman elektrokardiograf (selanjutnya disingkat EKG) data diskrit. Data gelombang yang berupa hasil grafik, diolah melalui pengolahan sinyal digital sehingga hasil gelombang didapatkan berupa data diskrit dan bisa diolah kembali menjadi data grafik. Durasi waktu antara peak R to peak R digunakan sebagai periode waktu tiap siklus. Pergeseran waktu mundur setengah HR merupakan akhir gelombang dari siklus sebelumnya dalam berupa tampilan aplikasi sehingga siapapun dapat mengaplikasikan dan melihat dara rekam medis secara real time dengan data masukan berupa data diskrit. Data diskrit dari MIT-BIH dan hasil pengukuran yang dilakukan sendiri digunakan sebagai data untuk memperoleh jumlah cycle dalam rekaman EKG, posisi R tiap siklus, durasi tiap siklus, dan nilai heart rate dengan menggunakan aplikasi software MATLAB. Hasil penelitian berupa data rekaman hasil EKG yang disimpan tidak lagi dalam bentuk gambar melainkan data diskrit, yang dapat ditampilkan secara real time.
\end{abstract}

Kata kunci: ECG, Matlab, Gelombang, Data Diskrit

ABSTRACT This research makes a method to represent in real time the duration of the wave of each cycle of the electrocardiograph record (hereinafter abbreviated EKG) discrete data. Wave data in the form of graphic results, processed through digital signal processing so that the wave results obtained in the form of discrete data and can be processed back into graph data. The duration of time between peak $\mathrm{R}$ to peak $\mathrm{R}$ is used as the time period of each cycle. The half-step backward shift of HR is the wave end of the previous cycle in the form of an app display so anyone can apply and view virgin medical records in real time with discrete data input data. Discrete data from MIT-BIH and self-measurement results are used as data to obtain the number of cycles in the ECG recording, the R position of each cycle, the duration of each cycle, and the heart rate by using the MATLAB software application. The result of research is the recording data of EKG result that is stored no longer in the form of picture but discrete data, which can be displayed in real time.

Keywords: ECG, Matlab, Waves, discrete data

\section{PENDAHULUAN}

Penelitian yang dirilis oleh Institute for Health Metrics and Evaluation (IHME) di University of Washington menyatakan bahwa salah satu penyebab kematian tertinggi di Indonesia yaitu penyakit Jantung. Selain itu, diperkuat oleh penelitian Global Burden of Desease Study 2013 yang menyatakan tentang serangan jantung dapat menyebabkan kematian bagi umat manusia. Infark miokardial atau serangan jantung yaitu terhentinya aliran darah menuju ke jantung, meskipun hanya sesaat, dan berakibat adanya kematian sebagain sel pada jantung. Kasus serangan jantung sering disebabkan karena adanya penyumbatan pembuluh darah dan terhentinya aliran darah (Dharma, 2016).

Selain penyumbatan pembuluh darah, serangan jantung sering terjadi pada penderita penyakit jantung koroner. Penyakit jantung koroner terjadi karena adanya plak pada bagian dalam arteri jantung yang biasanya disebut dengan atherosclerosis. Dalam kasus ini plak yang tidak ditangani dengan baik maka perlahan-lahan plak akan meningkat dan menyebabkan adanya penyempitan pembuluh darah. Adanya penyempitan pembuluh darah berakibat pada aliran darah pada pembuluh darah akan berkurang dan terjadinya penggumpalan keping-keping darah (trombosit) pada plak tersebut. Sehingga ketika terjadi pecahnya gumpalan keping darah pada pembuluh tersebut, maka berakibat terjadinya serangan jantung. Oleh karena itu, serangan jantung dikategorikan dalam penyakit gawat darurat, dengan alasan pada beberapa menit pertama akan menjadi tolok ukur penting bagi keberlangsungan hidup penderita. Dimana kerusakan atau gejala serangan ini dapat diperbaiki atau dilakukan penanganan khusus pada jam pertama saja ketika terjadi serangan jantung tersebut. Sedangkan selebihnya serangan jantung akan langsung bisa merusak otot jantung yang berakibat rasa sakit yang luar biasa pada dada, bahu, perut, dan rahang (Aishwarya, 2016).

Berdasarkan fakta di atas maka menjadi penting untuk mengetahui kondisi jantung lebih dini dalam ranah mengurangi resiko kematian yang disebabkan oleh serangan jantung. Salah satu upaya 
yang dapat dilakukan untuk mengetahui kondisi jantung yaitu dengan melakukan pemeriksaan Elektrokardiogram (EKG). EKG merupakan suatu representasi grafik yang dibuat oleh elektrokardiograf dengan merekam aktivitas kelistrikan detak jantung dalam rentang waktu tertentu. Pada umumnya elektrokardiograf yang diamati terdiri atas 12 lead, dimana pada prosesnya setiap lead tersebut akan dilengkapi bahan konduktif yang dipasang pada bagian anggota tubuh yang berfungsi sebagai alat pelacak sinyal listrik jantung. Jika perjalanan sinyal listrik jantung bergerak menuju ke lead maka menghasilkan garis naik pada grafik tersebut yang disebut defleksi positif, akan tetapi ketika perjalanan sinyal listrik jantung bergerak menjauhi lead maka menghasilkan garis turun pada grafik tersebut yang disebut defleksi negatif. Hasil rekaman EKG akan ditampilkan pada kertas perekam EKG dengan ukuran setiap kotaknya $1 \mathrm{~mm}^{2}$, dimana sebuah EKG khusus berjalan di atas kertas dengan kecepatan $25 \mathrm{~mm} / \mathrm{s}$ (Parente, 2017).

Suatu hasil rekaman EKG pada siklus satu periode dapat dihitung atau ditentukan melalui jarak peak to peak, akan tetapi masalah titik awal dan titik akhir dari suatu siklus sulit untuk diperoleh. Satu siklus merupakan waktu yang dibutuhkan untuk impuls dari sino atrial node hingga purkinje fibre dan berulang lagi. Dikarenakan dengan satu siklus tersebut dapat diperoleh informasi tentang ddiagnosa penyakit jantung seperti koroner, miocard infark, hiperthropy, fibrilasi, iskemia, dan aritmia. Oleh karena penting informasi tentang gelombang dalam satu siklus maka diperlukan untuk menentukan tiap satu siklus pada rekam gelombang EKG. Dengan gelombang satu siklus akan diperoleh nilai peak PQRST dan heart rate panjang lintasan gelombang dalam satu siklus. Hal ini dapat dilaksanakan dengan proses sampling pada frekuensi tertentu, dan proses sampling akan menghasilkan data dalam bentuk diskrit pada domain amplitudo fungsi gelombang waktu dengan satuan millivolt. Data diskrit EKG tersebut akan memberikan representasi tentang gelombang dalam bentuk data diskret yang memungkinkan untuk ditampilkan di layar monitor ataupun dicetak pada kertas khusus. Dengan demikian aplikasi hasil tersebut dapat digunakan oleh khalayak ramai dengan mudah untuk melihat data bentuk diskret tentang kondisi gelombang elektrokardhiografnya.

\section{LANDASAN TEORI}

\subsection{Gelombang Elektrokardiograf}

Adanya Impuls periodic yang dipancarkan oleh Sino Atrial node (pacu jantung alami) menyebabkan terjadinya systole/contraction dan diastole/relaxation pada otot-otot Jantung yang pada akhirnya menimbulkan gelombang denyut sebagai mekanisme dari pompa Jantung. Dalam satu siklus, impuls terpancar melalui jalur internodus atrium, AV node, bundle of HIS dan Purkinje fibre . Jantung berfungsi sebagai pompa untuk mengalirkan darah dari jantung ke paru (pulmonal) maupun dari jantung ke seluruh tubuh (perifer) . Gambar 1 memperlihatkan sistem kelistrikan Jantung. Jantung normal memiliki jumlah denyut per menit yang disebut dengan heart rate (HR) antara 60-100. Jika dibawah 60 disebut Bradicardia dan jika diatas 100 disebut Tachicardia (Soundarapandian, 2010).

Pemeriksaan Jantung dengan memakai Electrocardiograph akan diperoleh gelombang ECG yang direpresentasikan pada layar monitor ataupun kertas khusus ECG. Gelombang ini merupakan representasi dari bagian Jantung dari sisi Lateral, Inferior, septal dan anterior.

Gambar 1 memperlihatkan sistem kelistrikan Jantung, dalam gambar 2 memperlihatkan sisi Jantung yang diperiksa dan dalam gambar 3 memperlihatkan hasil pemeriksaan Jantung dengan electrocardiograph 12-lead (Thaler, 2006).

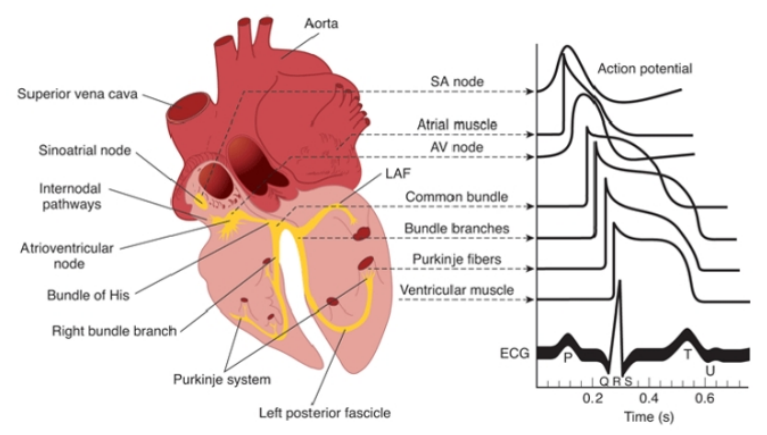

Gambar 1. Sistem kelistrikan Jantung http://www.softilmu.com 


\subsection{Data Diskrit}

Semua kondisi alami yang ada di dunia ini pada umumnya merupakan sinyal analog, yang kontinyu, yaitu fenomena atau gejala sebagai fungsi waktu. Diskrit disini artinya tidak saling berhubungan (lawan dari kontinyu). Objek yang dibahas dalam Matematika Diskrit - seperti bilangan bulat, graf, atau kalimat logika - tidak berubah secara kontinyu, namun memiliki nilai yang tertentu dan terpisah. Beberapa hal yang dibahas dalam matematika ini adalah teori himpunan, teori kombinatorial, permutasi, relasi, fungsi, rekursif, teori graf, dan lain-lain. Matematika diskrit merupakan mata kuliah utama dan dasar untuk bidang ilmu komputer atau informatika.

\subsection{Software Matlab}

MATLAB (Matrix Laboratory) adalah sebuah lingkungan komputasi numerikal dan bahasa pemrograman komputer generasi keempat. Dikembangkan oleh The MathWorks, MATLAB memungkinkan manipulasi matriks, pem-plot-an fungsi dan data, implementasi algoritma, pembuatan antarmuka pengguna, dan peng-antarmuka-an dengan program dalam bahasa lainnya. Meskipun hanya bernuansa numerik, sebuah kotak kakas (toolbox) yang menggunakan mesin simbolik MuPAD, memungkinkan akses terhadap kemampuan aljabar komputer. Sebuah paket tambahan, Simulink, menambahkan simulasi grafis multiranah dan Desain Berdasar-Model untuk sistem terlekat dan dinamik. Pada tahun 2004, MathWorks mengklaim bahwa MATLAB telah dimanfaatkan oleh lebih dari satu juta pengguna di dunia pendidikan dan industri (Abdia, 2006).

MATLAB (yang berarti "matrix laboratory") diciptakan pada akhir tahun 1970-an oleh Cleve Moler, yang kemudian menjadi Ketua Departemen Ilmu Komputer di Universitas New Mexico. Cleve Moler merancangnya untuk memberikan akses bagi mahasiswa dalam memakai LINPACK dan EISPACK tanpa harus mempelajari Fortran. Karyanya itu segera menyebar ke universitas-universitas lain dan memperoleh sambutan hangat di kalangan komunitas matematika terapan. Jack Little, seorang insinyur, dipertemukan dengan karyanya tersebut selama kunjungan Moler ke Universitas Stanford pada tahun 1983. Menyadari potensi komersialnya, ia bergabung dengan Moler dan Steve Bangert. Mereka menulis ulang MATLAB dalam bahasa pemrograman $\mathrm{C}$, kemudian mendirikan The MathWorks pada tahun 1984 untuk melanjutkan pengembangannya. Pustaka yang ditulis ulang tadi kini dikenal dengan nama JACKPAC. Pada tahun 2000, MATLAB ditulis ulang dengan pemakaian sekumpulan pustaka baru untuk manipulasi matriks (Gunawan, 2012).

MATLAB pertama kali diadopsi oleh insinyur rancangan kontrol (yang juga spesialisasi Little), tapi lalu menyebar secara cepat ke berbagai bidang lain. Kini juga digunakan di bidang pendidikan, khususnya dalam pengajaran aljabar linear dan analisis numerik, serta populer di kalangan ilmuwan yang menekuni bidang pengolahan citra.

\section{ANALISA DAN PERANCANGAN SISTEM}

\subsection{Analisa Masalah}

Permasalahan yang akan diselesaikan pada penelitian ini adalah bagaimana merepresentasikan data diskrit menjadi gelombang dengan representasi grafik seperti hasil pembacaan elektrokardiograf dan dapat dilihat secara real time beserta variable P,Q,R,S,T dan mampu memiliki akurasi sesuai pembacaan dan pengamatan para medis. Kerangka permasalahan ditunjukkan dalam Gambar 2. 


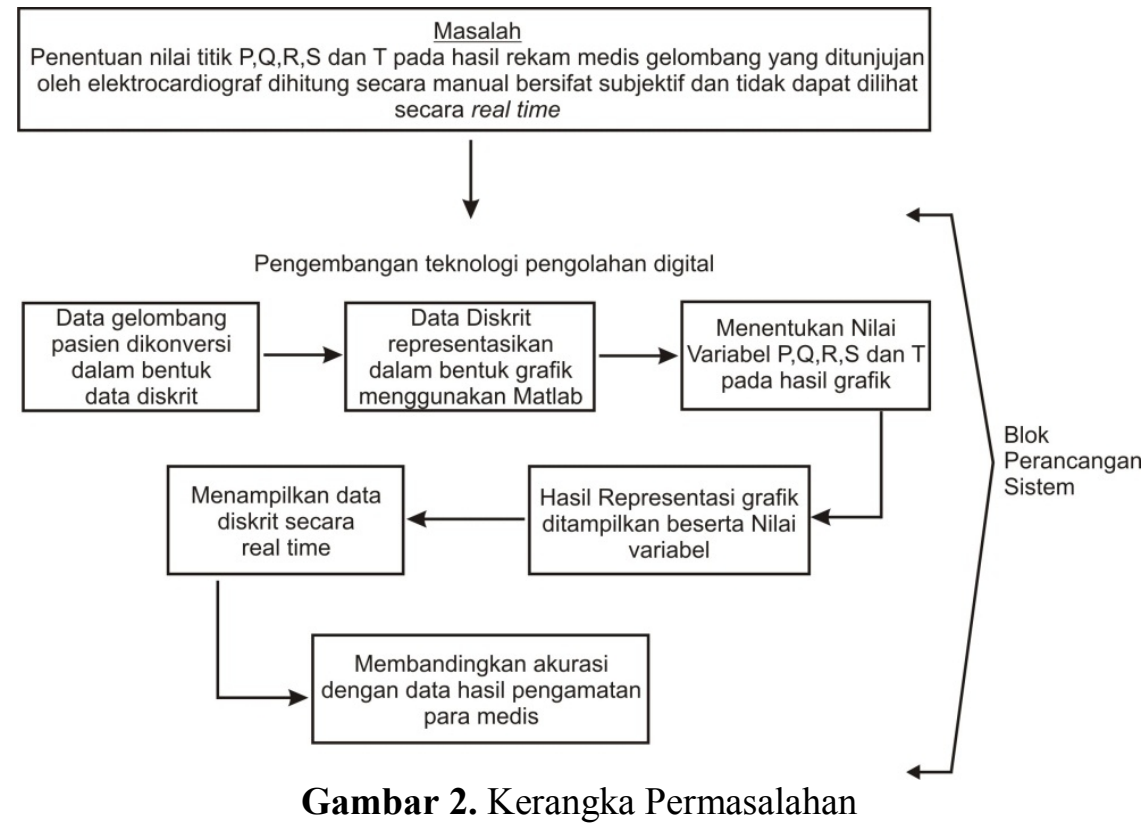

\subsection{Perancangan Sistem}

Pada penelitian ini perancangan yang akan dilakukan ditunjukkan pada gambar 2 . Perancangan sistem dilakukan berdasarkan hasil rekam medis pasien berupa data gelombang dikonversi dalam bentuk data diskrit. Hasil data diskrit yang telah dikonversi akan direpresentasikkan ulang dalam bentuk grafik ke dalam Matlab untuk dilakukan analisis. Setelah berhasil direpresentasikan maka hasil grafik dianalisis untuk menentukan variable berupa nilai $\mathrm{P}, \mathrm{Q}, \mathrm{R}, \mathrm{S}, \mathrm{T}$ pada grafik, yang kemudian hasil grafik akan ditampilkan secara real time, sehingga dapat dilihat kapan saja.

Hasil grafik yang akan ditampilkan juga disertakan hasil nilai variable yang telah dianalisis berdasarkan perhitungan dari grafik yang dihasilkan. Tahap selanjutnya adalah melakukan pengujian apakah data analisis dari grafik hasil representasi sama dengan hasil pengamatan dari pakar medis.

\subsection{Pembuatan Sistem}

Proses pembuatan aplikasi dibagi pengambilan data diskrit, merepresentasikan data menjadi grafik dan menentukan parameter variable P,Q,R,S,T sebagai berikut.

\section{A. Pengambilan Data Pasien}

Peralatan yang digunakan untuk melakukan pengambilan data rekam jantung pasien dengan representasi data diskrit ditunjukkan dalam Gambar 3 berikut.

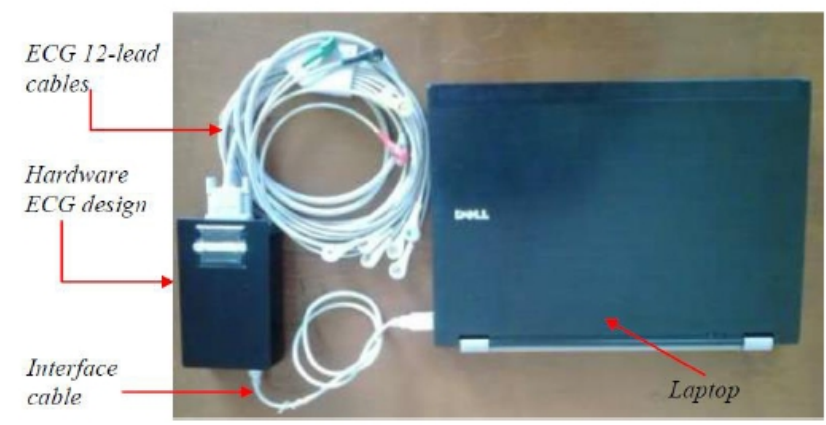

Gambar 3. Peralatan Rekam Jantung Data Diskrit

Berdasarkan gambar diatas, peralatan merupakan hasil penelitian yang telah dilakukan dan telah diuji. Dengan menggunakan perlatan diatas, maka pasien dapat dilakukan perekaman jantung, dan mendapatkan data berupa data diskrit yang akan diolah lebih lanjut dalam penelitian ini. Adapun spesifikasi yang digunakan untuk dapat melakukan pengujian alat adalah sebagai berikut 12 kabel 
lead, 1 buah kotak hardware untuk mengolah data menjadi data diskrit, 1 buah kabel antar muka hardware dengan laptop, 1 buah laptop untuk membaca jalannya data (Setiawidayat, 2016).

Hasil konversi data grafik menjadi data diskrit berdasarkan hasil penelitian sebelumnya ditunjukkan dalam Tabel berikut.

Tabel 1. Hasil Konversi Data Diskrit

\begin{tabular}{|c|c|c|c|c|c|c|c|c|c|c|c|c|}
\hline No & $\begin{array}{c}\text { Lead I } \\
\text { (mv) }\end{array}$ & $\begin{array}{c}\text { Lead II } \\
\text { (mv) }\end{array}$ & $\begin{array}{c}\text { lead III } \\
(\mathrm{mv})\end{array}$ & $\begin{array}{c}\text { Avl } \\
(\mathrm{mv})\end{array}$ & $\begin{array}{l}\text { AvR } \\
(\mathrm{mv})\end{array}$ & $\begin{array}{l}\text { AvF } \\
(\mathrm{mv})\end{array}$ & $\begin{array}{c}\mathrm{v} 1 \\
(\mathrm{mv})\end{array}$ & $\begin{array}{c}\mathrm{v} 2 \\
(\mathrm{mv})\end{array}$ & $\begin{array}{c}\text { v3 } \\
\text { (mv) }\end{array}$ & $\begin{array}{c}\mathrm{v} 4 \\
(\mathrm{mv})\end{array}$ & $\begin{array}{c}\text { v5 } \\
\text { (mv) }\end{array}$ & $\begin{array}{c}\text { v6 } \\
\text { (mv) }\end{array}$ \\
\hline 1 & -0.1626 & -0.1704 & -0.0078 & 0.1665 & -0.0774 & -0.0891 & 0.2041 & 0.0745 & 0.0079 & -0.0746 & -0.0356 & -0.0645 \\
\hline 2 & -0.1611 & -0.1661 & -0.005 & 0.1636 & -0.0781 & -0.0856 & 0.1982 & 0.0729 & 0.004 & -0.0755 & -0.0364 & -0.0669 \\
\hline 3 & -0.1613 & -0.1631 & -0.0018 & 0.1622 & -0.0798 & -0.0825 & 0.1975 & 0.072 & 0.0012 & -0.0779 & -0.0392 & -0.0687 \\
\hline 4 & -0.1613 & -0.1611 & 0.0002 & 0.1612 & -0.0808 & -0.0805 & 0.2014 & 0.073 & 0.0007 & -0.0791 & -0.0414 & -0.0697 \\
\hline 5 & -0.161 & -0.1614 & -0.0004 & 0.1612 & -0.0803 & -0.0809 & 0.2061 & 0.0758 & 0.002 & -0.0782 & -0.0416 & -0.0699 \\
\hline 6 & -0.1592 & -0.1635 & -0.0043 & 0.1613 & -0.0775 & -0.0839 & 0.2073 & 0.0785 & 0.0027 & -0.0758 & -0.0406 & -0.0701 \\
\hline . &. & . &. & . & . & . & . & $\cdot$ & . & . &. & $\cdot$ \\
\hline . & . & . & . & . & . & . & . & . & . & . & . & . \\
\hline . & . & . & . & . & . & . & . & . & . & . & . & . \\
\hline 1495 & -0.1709 & 0.0966 & 0.2675 & 0.0372 & -0.2192 & 0.182 & 0.0841 & -0.0047 & -0.079 & -0.132 & -0.2437 & -0.2072 \\
\hline 1496 & -0.1633 & 0.0902 & 0.2535 & 0.0366 & -0.2084 & 0.1718 & 0.0932 & 0.0134 & -0.063 & -0.1228 & -0.2396 & -0.2118 \\
\hline 1497 & -0.1549 & 0.092 & 0.2469 & 0.0315 & -0.2009 & 0.1694 & 0.099 & 0.0238 & -0.0466 & -0.1077 & -0.2298 & -0.2096 \\
\hline 1498 & -0.1472 & 0.098 & 0.2452 & 0.0246 & -0.1962 & 0.1716 & 0.1029 & 0.031 & -0.0334 & -0.0923 & -0.2181 & -0.2036 \\
\hline 1499 & -0.1427 & 0.1002 & 0.2429 & 0.0213 & -0.1928 & 0.1715 & 0.105 & 0.0374 & -0.0264 & -0.0836 & -0.2107 & -0.2003 \\
\hline 1500 & -0.1454 & 0.0948 & 0.2402 & 0.0253 & -0.1928 & 0.1675 & 0.1068 & 0.0417 & -0.0256 & -0.0843 & -0.2108 & -0.2027 \\
\hline
\end{tabular}

\section{B. Perancangan Representasi Data dengan Matlab}

Proses perancangan representasi data diskrit ke dalam grafik menggunakan Matlab ditunjukkan dalam diagram alir sebagai berikut:

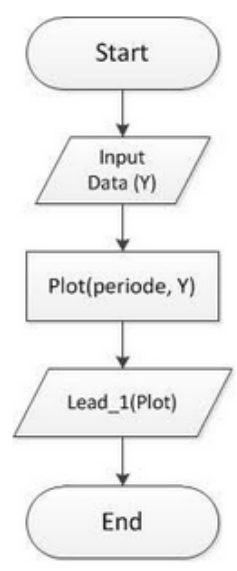

Gambar 4. Diagram Alir Perancangan

Berdasarkan data hasil konversi ke dalam data diskrit yang telah dipaparkan sebelumnya maka hasil data konversi direpresentasikan ke dalam bentuk grafik sehingga dapat dilihat apakah data dapat dianalisis atau tidak dan melihat kesesuaian data dengan hasil rekam jantung laboratorium. Berikut adalah hasil perancangan representasi grafik. 


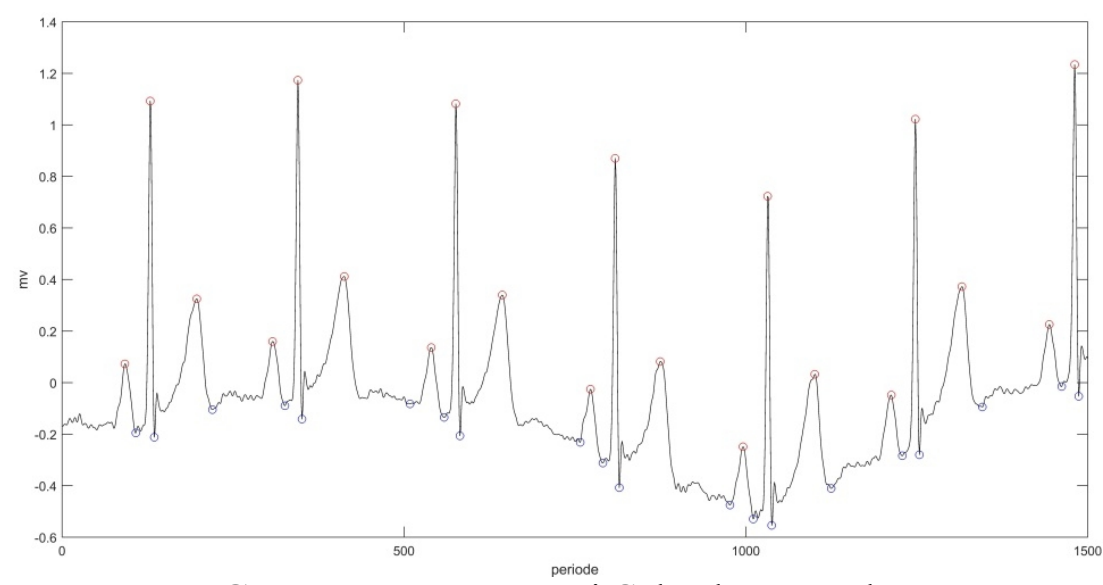

Gambar 5. Representasi Gelombang Lead I

\section{Perhitungan Variabel P,Q,R,S,T}

Analisis perancangan dalam penentuan nilai variable PQRST berdasarkan data representasi grafik menggunakan Matlab ditunjukkan dalam diagram alir analisis perhitungan sebagai berikut.

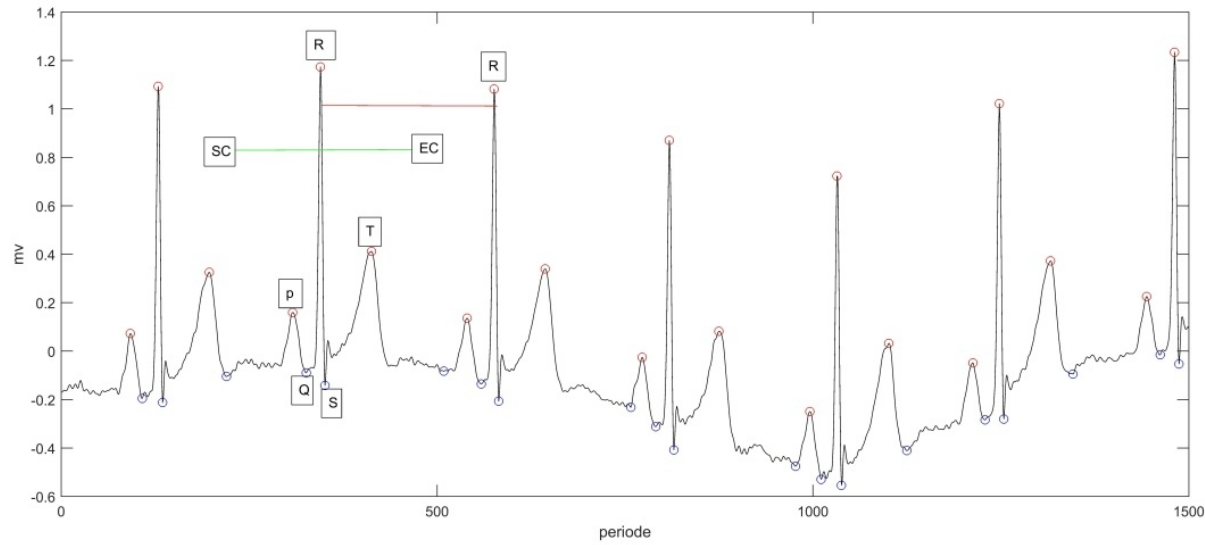

Gambar 6. Variabel PQRST

Untuk penentuan variable pada grafik hasil rekam jantung, maka dibutuhkan perhitungan untuk masing-masing variable $\mathrm{P}, \mathrm{Q}, \mathrm{R}, \mathrm{S}, \mathrm{T}$. Berikut adalah proses analisis perhitungan variable berdasarkan diagram alir yang ditunjukkan dalam Gambar 8. Dan untuk acuan perhitungan variabel PQRST didapatkan berdasarkan perhitungan pada gambar 9 menghitung nilai PQRST pada lead II dengan cara sebagai berikut:

1. Mencari nilai tertinggi dari grafik ECG dinamakan Nilai R,

2. Nilai R-R dengan mengukur panjang $\mathrm{R}$ ke $\mathrm{R}$ selanjutnya.

3. Nilai $S C=R-\frac{R \rightarrow R}{2}$

4. Nilai $E C=R+\frac{R \rightarrow R}{2}$

5. Nilai tertinggi antara $S C \rightarrow R=P$

6. Nilai terendah antara $S C \rightarrow R=Q$

7. Nilai tertinggi antara $R \rightarrow E C=T$

8. Nilai terendah antara $R \rightarrow E C=S$ 


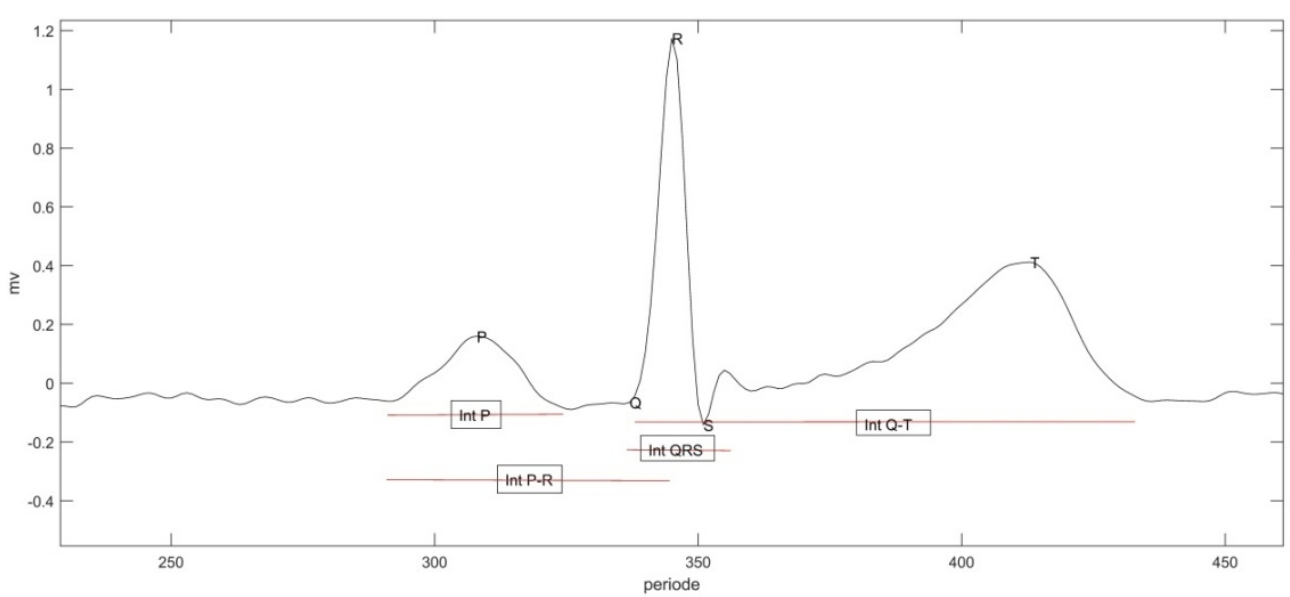

Gambar 7. Perhitungan Interval P-R, Q-T, QRS, P

Pada Gambar 7 memberikan langkah untuk menghitung interval P pada grafik garis naik dan turun pada $P$, interval $P-R$ pada jarak antara titik naik $P$ sampai pada $R$, interval QRS merupakan jarak antara $\mathrm{Q}$ sampai $\mathrm{S}$ yang melewati $\mathrm{R}$, dan interval Q-T merupakan jarak antara $\mathrm{Q}$ sampai garis turun pada nilai $T$.

Pada perhitungan PQRST akan ditampilkan dalam bentuk grafik menggunakan program Matlab dengan cara memasukkan data dan melakukan plot terhadap data yang telah didapatkan dan kemudian ditampilkan dalam bentuk Grafik seperti ditunjukkan dalam Gambar 8.

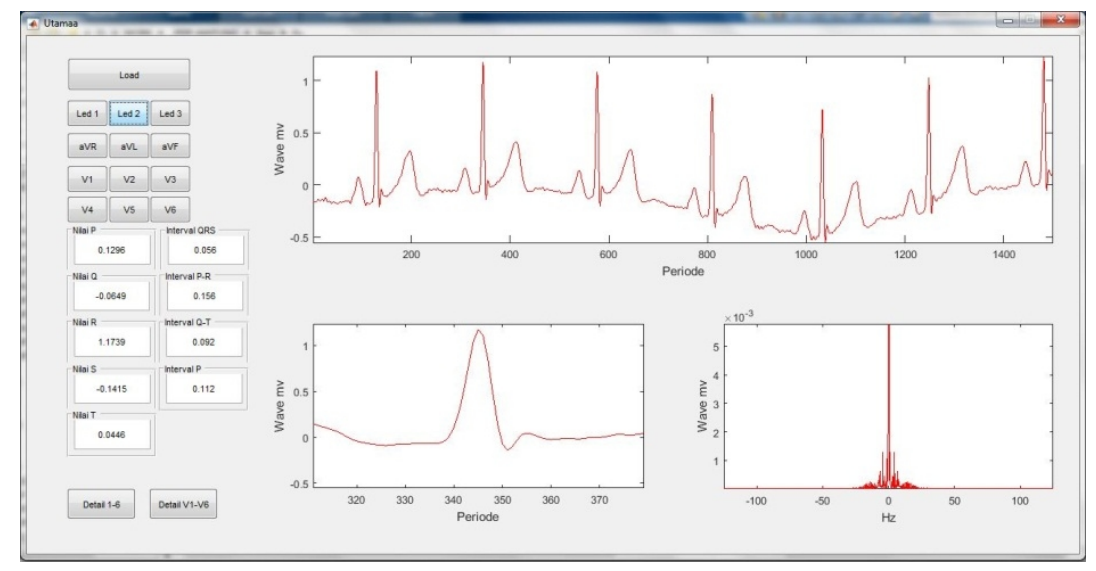

Gambar 8. Perhitungan PQRST Lead II

\section{$4 \quad$ Pengujian}

Hasil pengujian dengan membandingkan perhitungan data diskrit dengan matlab dengan validasi dokter menghasilkan. Pada perbandingan ini melihat pada lead 1 untuk dibandingkan dengan hasil validasi dokter spesialis jantung.

Tabel 2. Hasil Pengujian data diskrit dengan validasi dokter

\begin{tabular}{|c|c|c|c|c|c|}
\hline No & Nama & $\begin{array}{c}\text { Interval } \\
\text { Grafik }\end{array}$ & $\begin{array}{c}\text { Data Hasil Penelitian } \\
\text { Diskrit (s) }\end{array}$ & $\begin{array}{c}\text { Hasil Dokter } \\
(\mathrm{s})\end{array}$ & $\begin{array}{c}\text { Error } \\
(\mathrm{s})\end{array}$ \\
\hline \multirow{2}{*}{1} & \multirow{2}{*}{ Andar } & QRS & 0.056 & 0.04 & 0.016 \\
\cline { 3 - 6 } & & P-R & 0.188 & 0.16 & 0.028 \\
\cline { 3 - 6 } & & Q-T & 0.396 & 0.32 & 0.076 \\
\hline \multirow{2}{*}{2} & \multirow{2}{*}{ Budi } & P & 0.072 & 0.08 & 0.008 \\
\cline { 3 - 6 } & & QRS & 0.152 & 0.12 & 0.032 \\
\cline { 3 - 6 } & & P-R & 0.132 & 0.16 & 0.028 \\
\cline { 3 - 6 } & & Q-T & 0.427 & 0.36 & 0.067 \\
\hline 3 & Masda & QRS & 0.052 & 0.08 & 0.064 \\
\cline { 3 - 6 } & & P-R & 0.056 & 0.20 & 0.032 \\
\hline
\end{tabular}




\begin{tabular}{|c|c|c|c|c|c|}
\hline \multirow{3}{*}{} & Q-T & 0.128 & 0.12 & 0.008 \\
\cline { 3 - 6 } & P & 0.1 & 0.1 & 0 \\
\hline \multirow{4}{*}{4} & \multirow{2}{*}{ Rumanti } & QRS & 0.240 & 0.20 & 0.04 \\
\cline { 3 - 6 } & & P-R & 0.081 & 0.16 & 0.079 \\
\cline { 3 - 5 } & Q-T & 0.172 & 0.24 & 0.068 \\
\hline & P & 0.040 & 0.08 & 0.04 \\
\hline & \multicolumn{3}{|c|}{ Jumlah } & 0.614 \\
\hline
\end{tabular}

Hasil validasi dokter pada grafik ECG didapatkan error yang sangat kecil terhadap nilai interval waktu. Hasil jumlah error didapatkan 0.614 dengan data sebanyak 16, sehingga nilai

$$
M A P E=\frac{0.614}{16}=0.038375
$$

sehingga dengan menggunakan program matlab yang dirubah menjadi bentuk diskrit menghasilkan nilai yang tidak berbeda dari hasil pengamatan dokter spesialis jantung.

\section{PENUTUP}

Pada penelitian ini membuat program untuk membaca grafik ECG diskrit yang digunakan mencari PQRST pada grafik tersebut. PQRST digunakan untuk mengukur detak jantung pada setiap lead. Berdasarkan hasil pengujian didapatkan bahwa dengan membandingkan hasil diskrtit matlab dengan validasi ECG dokter menghasilkan MAPE 0.038375. Hasil rekam diskrit ini diharapkan dapat memberikan pengetahuan pasien hasil rekam jantung pasien, sehingga memperkecil kesalahan perhitungan pada grafik ECG.

\section{DAFTAR PUSTAKA}

Abdia, Gunaidi. (2006). Matrix Laboratory Matlab Programming. Bandung: Informatika Bandung

Aishwarya, Karthik Kumar, Madhukumar, Meghana K M. (2016). Real Time Wireless Ecg Monitoring System. Karnataka State Council for Science and Technology, IISc, Bangalore560012

Dharma, Surya.(2016). Cara Mudah Membaca ECG. Jakarta: Buku kedokteran ECG.

Gunawan, Dadang, Filbert Hilman Juwono. (2012). Pengolahan Sinyal Digital Dengan Program Matlab. Yogyakarta:Graha Ilmu.

Parente, Francesca Romana Dkk. (2017). An Electronic System for the Contactless Reading of ECG Signals. Sensors 2017, 17, 2474; doi: 10.3390/s17112474

Setiawidayat, Sabar. Putri, Suci Imani. (2016). Filtering data diskrit elektrokardiogram Untuk penentuan PQRST dalam satu siklus. Prosiding SENTIA 2016 - Politeknik Negeri Malang. Volume 8 - ISSN: 2085-2347

Soundarapandian, Karthik, Mark Berarducci.(2010). Analog Front-End Design for ECG Systems Using Delta-Sigma ADCs. SBAA160A - March 2009 - Revised April 2010

Thaler, Malcolm S. (2006). Satu-Satunya Buku EKG yang Anda Perlukan Edisi 5. Jakarta: Buku kedokteran ECG. 